\title{
Effect of Morphological Characters of Indigenous Sugarcane Varieties on Population of Chilo infuscatellus (Snellen) and its parasitoid, Cotesia flavipes (Cameron)
}

\section{Bina Khanzada ${ }^{1}$, Arfan Ahmed Gilal ${ }^{1 *}$, Bhai Khan Solangi ${ }^{1}$ and Imtiaz Ahmed Nizamani ${ }^{2}$}

\section{${ }^{1}$ Department of Entomology, Faculty of Crop Protection, Sindh Agriculture University, Tandojam, Pakistan; ${ }^{2}$ Department of} Plant Protection, Faculty of Crop Protection, Sindh Agriculture, University, Tandojam, Pakistan.

\begin{abstract}
Sugarcane stem borer, Chilo infuscatellus Snellen. has caused severe losses in cane growing areas of Pakistan. Among natural enemies, Cotesia flavipes Cameron has been widely used in different regions of the world for its management. Considering the significant role of morphological characters of sugarcane varieties on infestation of $C$. infuscatellus, thus, on parasitism of $C$. flavipes, this study was conducted in 2013 and 2014. Ten sugarcane varieties i.e., NIA-98, NIA-2004, Thatta-10, Gulab-95, BL-4, L-116, SPS-26, AEC86223, AEC82-1026 and Larkana-201 were used in the study, each sown on half acre area at Experimental field of Nuclear Institute of Agriculture, Tando Jam, Pakistan. Observations were taken on morphological characters of varieties i.e., cane length, number of internodes, length of leaf, sheath, trichome density along with infestation and larval population of $C$. infuscatellus and parasitism of $C$. flavipes were recorded. Results indicated a high variation in the morphological characters of different sugarcane varieties evaluated, that in response affected the population of both $C$. infuscatellus and its parasitoid, $C$. flavipes. Among varieties, the highest population of $C$. infuscatellus was recorded on Thatta-10 variety, whereas, L-116 suffered the lowest damage. The population trend of $C$. infuscatellus on remaining varieties was recorded in the order of AEC821026 > AEC-86-223 > Gulabi-95 > SPSG-26 > BL-4 > Larkan-2001 > NIA- 2004 > NIA-98 > 98 . In continuation of the maximum population of $C$. infuscatellus, the highest the highest parasitism of $C$. flavipes on $C$. infuscatellus was also recorded on Thatta-10, and the lowest parasitism on L-116 variety. Moreover, among morphological characters, only the number of internodes showed a significant influence the infestation and larval population of $C$. infuscatellus along with parasitism of $C$. flavipes. Therefore, it is suggested that cultivation of susceptible varieties should be avoided to restrict the infestation of $C$. infuscatellus.

Received | October 14, 2020; Accepted | December 31, 2020; Published | March 03, 2021

*Correspondence | Arfan Ahmed Gilal, Department of Entomology, Faculty of Crop Protection, Sindh Agriculture University, Tandojam, Pakistan; Email: aagilal@sau.edu.pk

Citation | Khanzada, B., A.A. Gilal, B.K. Solangi and I.A. Nizamani. 2021. Effect of morphological characters of indigenous sugarcane varieties on population of Chilo infuscatellus (Snellen) and its parasitoid, Cotesia flavipes (Cameron). Pakistan Journal of Agricultural Research, 34(1): 154-163. DOI | http://dx.doi.org/10.17582/journal.pjar/2021/34.1.154.163

Keywords | Infestation, Plant morphology, Stem borer, Sugarcane, Varieties
\end{abstract}

\section{Introduction}

Sugarcane (Saccharum officinarum L.) is presently Sconsidered as a cash crop in Pakistan due to high cash values (Hussain et al., 2007). However, presently many factors are responsible for its lower yield and marketing values in the country i.e., low per acre yield, sugar recovery and higher cost of production (Arian et al., 2011). Although, there are many reasons for the lower yield of sugarcane in the country, but the yield losses due to attack of borer is the most significant. Among the borers, stem borer, Chilo infuscatellus 
Snellen is the most notorious and destructive pest of sugarcane (Raza et al., 2014). It is more active and damaging during March to November, whereas, it overwinters in stubbles as full-grown larvae. The most significant symptom of its damage is dead hearts, yield losses of $30-70 \%$ is reported due to its attack (Shahid et al., 2007; Sajid and Hamed, 2011). Mainly, granular pesticides are used for the management of C. infuscatellus; however, their continuous indiscriminate use has caused many negative impacts i.e., development resistance, environmental pollution and hazards to humans and livestock (Mohyuddin et al., 1997; Soerjani, 1998).

Cotesia flavipes cameron is a gregarious larval endoparasitoid that feeds on large to medium sized larvae of borers attacking gramineae family (Ngi-Song and Overholt, 1995; Raza et al., 2014). Although, native to South and South-east Asia, C. flavipes has successfully established in many countries of the world against many noxious lepidopteran borers (Murrihead et al., 2006). It has also shown promising impacts against C. infuscatellus in Sindh, Pakistan (Khan et al., 2013).

It has been established that host plant resistance always played a significant role in infestation by pests and also on the occurrence and abundance of their natural enemies at no additional cost (Mondal et al., 2012). This variation in pest infestation and natural enemy population may be attributed towards the morphological characteristics of plants i.e., cane length, sheath length, number of internodes, number of trichomes etc. In sugarcane, Raza et al. (2014) reported the significant role of various morphological characters of varieties on reducing the infestation of $C$. infuscatellus and the performance of their parasitoids especially Trichogramma chilonis. Thus, aim of this study is to evaluate the role of various morphological characteristics of sugarcane varieties on the incidence of C. infuscatellus and its parasitoid, C. flavipes.

\section{Materials and Methods}

\section{Experimental area}

The study was conducted in 2013-2014 at agriculture field of Nuclear Institute of Agriculture (NIA), Tando Jam, Pakistan.

\section{Experimental setup, data collection and analysis}

Ten commercially cultivated sugarcane varieties of Sindh i.e., NIA-98, NIA-2004, Thatta-10, Gulab-95,
BL-4, L-116, SPS-26, AEC86-223, AEC82-1026 and Larkana-201 were used in the study. Each variety was grown in a half-acre field in a randomized complete block design (RCBD), whereas, four replications were maintained for each variety. All the agronomic practices from sowing till harvesting of each variety was standardized. The data collection was started one month after the plantation of sugarcane and continued till harvesting. Ten canes from each variety were randomly selected per block to record the population of $C$. infuscatellus, infestation percentage of the borer and rate of parasitism of $C$. flavipes on the borer. In order to estimate the rate of parasitism, the collected larvae of $C$. infuscatellus were brought to the laboratory of NIA for further development and confirmation of parasitism.

Moreover, various morphological characters i.e., length of leaf along with sheath, trichome density, cane height and internode length were also recorded from the randomly selected ten canes of each variety as mentioned above. Correlation was performed to determine the influence of morphological characters of sugarcane varieties on the $C$. infuscatellus infestation and the rate of parasitism of C. flavipes.

Number of trichomes were determine by cutting oneinch sheath from top, middle and bottom of the plant and brought to the laboratory of Plant Protection Department, Sindh Agriculture University Tandojam and counted using a fine needle under an electron microscope. The length of cane was measured using measuring tape from top to bottom of the stalk. Total leaf length including the sheath was also measured along with counting of internodes per cane for each sugarcane variety.

\section{Data analysis}

Analysis of Variance was used to analyze the data, whereas the Least Significant Difference (LSD) was used to compare means with significant differences. Correlation was performed to determine the relationship of population of $C$. infuscatellus and its parasitoid C. flavipes with various morphological characters of sugarcane varieties.

\section{Results and Discussion}

Important morphological characters of sugarcane varieties in relation to infestation of $C$. infuscatellus and its parasitoid C. flavipes during 2013. 
Table 1 showed the important morphological characteristics of various sugarcane varieties and their impact on the population of stem borer, C. infuscatellus and its parasitoid, $C$. flavipes. The detailed results are given hereunder:

\section{Number of internodes}

According to results, a significant difference $(\mathrm{P}<$ 0.05) was recorded among sugarcane varieties for the number of internodes. The results revealed that maximum number of internodes $(25.87 \pm .23$ internodes/cane) were recorded in Thatta-10, followed by AEC86-223 (24.75 \pm 2.24 internodes/ cane) and AEC-82-1026 (23.70 \pm 2.16 internodes/ cane). The minimum internodes in a single cane were recorded in NIA-98 (17.16 \pm 1.38 internodes/ cane), followed by SPSG-26 (17.89 2.06 internodes / cane). Moreover, the remaining sugarcane varieties NIA-2004， L-116， Larkana-2001， Gulabi-95 and BL-4 produced $22.09 \pm 2.42$ internodes/ cane, $21.67 \pm 2.00$ internodes/ cane, $20.52 \pm 1.14$ internodes/ cane, $19.84 \pm 1.75$ internodes/ cane and $18.05 \pm 1.35$ internodes/ cane, respectively.

\section{Cane length}

Results in Table 1 shows significant $(\mathrm{P}<0.05)$ variation in cane length for different sugarcane varieties. Results revealed that the longest canes $(224.05 \pm 14.90 \mathrm{~cm})$ were obtained for variety NIA2004, followed by AEC-82-1026 $(216.82 \pm 13.59 \mathrm{~cm})$ and AEC-86-223 $(193.41 \pm 12.21 \mathrm{~cm})$. Among all the planted varieties, BL-4 variety, was observed as the shortest in length which produced $96.13 \pm 3.62$ $\mathrm{cm}$ canes, followed by SPSG-26 $(115.77 \pm 4.23 \mathrm{~cm})$. Cane length for remaining varieties observed were L-116 (183.97 $\pm 12.38 \mathrm{~cm})$, Thatta-10 $(162.03 \pm 8.68$ $\mathrm{cm} /$ cane), NIA-98 (151.19 $\pm 9.56 \mathrm{~cm})$, Larkana-2001 $(140.52 \pm 5.70 \mathrm{~cm}$ and Gulabi-95 $(126.75 \pm 10.21 \mathrm{~cm}$.

\section{Leaflength}

The length of leaves for all the tested sugarcane varieties was measured and the results in Table 1 shows that the maximum leaf length $(20.68 \pm 1.14$ $\mathrm{cm}$ ) was recorded in variety Larkana-2001 which was closely followed by AEC-82-1026 $(20.14 \pm 1.27 \mathrm{~cm})$. Relatively reduced or short leaves was recorded in NIA-2004 $(18.38 \pm 0.87 \mathrm{~cm})$, Thatta-10 $(17.14 \pm 1.03$ $\mathrm{cm}), \quad$ AEC-86-223 (16.96 $\pm 0.81 \mathrm{~cm}), \quad$ NIA-98 $(16.61 \pm 0.42 \mathrm{~cm})$ and SPSG-26 $(15.50 \pm 0.07 \mathrm{~cm})$. The minimum leaf length was recorded in Gulabi-95 $(12.64 \pm 0.35 \mathrm{~cm})$, followed by L-116 $(13.82 \pm 0.34 \mathrm{~cm})$ and BL-4 $(14.38 \pm 0.23 \mathrm{~cm})$. Thus, the significant $(\mathrm{P}<$ 0.05.) difference was observed in leaf length among different cultivated sugarcane varieties.

\section{Sheath length}

The measured length of sheath showed significant $(\mathrm{P}$ $<0.05)$ variation among cane varieties studies and is represented in Table 1 . The maximum sheath length $(6.86 \pm 0.74 \mathrm{~cm})$ was recorded for AEC-86-223 variety, followed by Gulabi-95 $(5.64 \pm 0.62 \mathrm{~cm})$ and Larkana-2001 $(5.48 \pm 0.43 \mathrm{~cm})$ varieties. Among the varieties, the shortest sheath length $(2.66 \pm 0.23 \mathrm{~cm})$ was observed in BL-4 variety, followed by AEC-821026 sugarcane variety $(2.86 \pm 0.22 \mathrm{~cm})$.

\section{Trichromes at top sheath}

The results regarding the number of trichomes on top sheath indicated that the maximum number of trichomes were observed in NIA-2004 variety $(58.15 \pm 3.36$ trichomes per one-inch sheath), followed by AEC-86-223 (57.75 \pm 3.19 trichomes per one inch sheath), and Larkana-2001 (56.05 \pm 3.22 trichomes per one-inch sheath). The lowest number trichomes on top sheath was counted on Gulabi-95 variety (14.25 \pm 0.12 trichomes per one-inch sheath), followed by BL-4 (16.15 \pm 0.10 trichomes per one-inch sheath) and Thatta-10 $(16.80 \pm 0.11$ trichomes per one-inch sheath) varieties (Table 1 ).

\section{Mid sheath trichomes}

The results regarding mid sheath trichomes is also presented in Table 1 that indicated a significant $(\mathrm{P}<0.05)$ variation in trichomes counted among sugarcane varieties. The highest and lowest number of trichomes on mid sheath were recorded on Larkana-2001 (156.40 \pm 0.18 trichomes per oneinch sheath) and BL-4 (59.90 \pm 0.13 trichomes per one-inch sheath) varieties, respectively. The number of trichomes recorded on mid sheath of remaining varieties were NIA-2004 (153.50 \pm 0.79 trichomes per one-inch sheath), AEC-82-1026 (142.10 \pm 0.21 trichomes per one inch sheath), AEC-86-223 (125.65 \pm 0.17 trichomes per one-inch sheath), NIA98 (121.75 \pm 0.10 trichomes per one-inch sheath), L-116 (98.95 \pm 0.10 trichomes per one-inch sheath), SPSG-26 (78.90 \pm 0.17 trichomes per one-inch sheath), Thatta-10 (69.25 \pm 0.17 trichomes per oneinch sheath) and Gulabi-95 (65.45 \pm 0.22 trichomes per one-inch sheath). 
Bottom sheath trichomes

According to results obtained during 2013 study, the maximum number for bottom sheath trichomes (71.40 \pm 2.20 trichomes per one-inch sheath) was counted in Larkana-2001, whereas Gulabi-95 variety possessed the lowest number of trichomes on bottom sheath i.e., $16.20 \pm 1.24$ trichomes per one-inch sheath (Table 1). The number of trichomes recorded in NIA-2004, AEC-86-223, AEC-82-1026, NIA-98, SPSG-26, BL-4, Thatta-10, and L-116 varieties were $66.70 \pm 2.42,59.80 \pm 3.08,58.40 \pm 3.14,45.65 \pm 2.15$, $22.90 \pm 2.26,19.90 \pm 2.06,18.35 \pm 1.09$, and $16.90 \pm 1.13$ trichomes per one-inch sheath, respectively (Table 1).

\section{Stem borer infestation percentage}

The infestation percentage caused by $C$. infuscatellus on different sugarcane varieties varied significantly ( $\mathrm{P}$ $<0.05)$. According to results, the highest infestation percentage by $C$. infuscatellus larvae $(16.80 \pm 1.45 \%)$ was observed on Thatta-10 sugarcane variety, followed by AEC-82-1026 (14.89 $1.19 \%)$ and AEC-86-223 $(10.98 \pm 1.02 \%)$. Moreover, the lowest infestation percentage due to the attack of $C$. infuscatellus was recorded on L116 (1.70 $\pm 0.12 \%)$ variety, followed by NIA-98 (4.15 $\pm 0.47 \%)$ and NIA-2004 (4.36 \pm 0.33 $\%)$ varieties. The infestation percentage recorded on remaining varieties i.e., Gulabi-95, SPSG-26, BL-4 and Larkana-2001 were $7.72 \pm 1.00 \%, 6.64 \pm 0.85 \%$, $6.64 \pm 0.44 \%$ and $6.17 \pm 0.75 \%$, respectively (Table 1 ).

\section{Larval population}

The larval population of $C$ infuscatellus observed on different sugarcane varieties is given in Table 1 . The results show that sugarcane varieties have significant $(\mathrm{P}<0.05)$ effect on larval population as the highest population of larvae per cane was recorded in Thatta-10 variety $(21.00 \pm 0.02$ larvae/cane). Moreover, the lowest number of larvae per can was recorded in L-116 (0.38 \pm 0.02 larvae/cane), followed by NIA-98 variety $(0.46 \pm 0.02$ larvae/cane).

\section{Parasitism percentage}

The parasitism percentage of $C$. flavipes on $C$. infuscatellus attacking different sugarcane varieties is shown in Table 1. Analysis of variance revealed that there was a significant $(\mathrm{P}<0.05)$ variation among sugarcane varieties to affect the parasitism of $C$. flavipes on C. infuscatellus. Maximum parasitism percentage $(0.61 \pm 0.01 \%)$ was recorded on larvae collected from L-116 variety, followed by AEC$86-223$ sugarcane variety $(0.14 \pm 0.01 \%)$. The lowest parasitism percentage of $C$. flavipes on $C$. infuscatellus larvae i.e., 2.06 $\pm 0.01 \%$ was observed from SPSG-26, BL-4 and NIA-98 sugarcane varieties.

Important morphological characters of sugarcane varieties in relation to infestation of $C$. infuscatellus and its parasitoid C. flavipes during 2014.

\section{Number of internodes}

The results regarding number of internodes counted for various sugarcane varieties showed almost similar trend as that of 2013, where maximum number of internodes $(28.33 \pm 2.23$ internodes/cane) was recorded in AEC-86-223 variety, followed by Thatta10 and AEC-82-1026 varieties with 27.11 \pm 2.06 and $27.10 \pm 2.27$ internodes / cane, respectively. Moreover, the minimum internodes $(18.63 \pm 1.19$ internodes/ cane) were observed in BL-4 variety, followed by NIA-98 variety (19.94 \pm 1.15 internodes / cane). Thus, overall a highly significant $(\mathrm{P}<0.001)$ difference was noted among sugarcane varieties regarding the number of internodes (Table 2).

\section{Cane length}

A high variation with significant difference $(\mathrm{P}<$ 0.001) was also recorded for the length of canes among sugarcane varieties studied (Table 2). The results indicated that NIA2004 variety produced the longest canes $(220.45 \pm 5.74 \mathrm{~cm})$, whereas BL-4 was the shortest variety having can length of $89.45 \pm 2.21$ $\mathrm{cm}$. The cane length recorded for remaining varieties i.e., Larkana-2001, Thatta-10, SPSG-26, NIA-98, L-116, AEC-821026, AEC-86-223 and Gulabi-95 were $121.22 \pm 3.13 \mathrm{~cm}, 113.20 \pm 2.07 \mathrm{~cm}, 105.42 \pm 2.17$ $\mathrm{cm}, 137.20 \pm 3.15 \mathrm{~cm}, 116.28 \pm 4.54 \mathrm{~cm}, 178.23 \pm 4.73$ $\mathrm{cm}, 195.51 \pm 5.17 \mathrm{~cm}$ and $118.84 \pm 3.54 \mathrm{~cm}$, respectively.

\section{Leaf length}

The results regarding the leaf length exhibited that the maximum leaf length $(20.94 \pm 1.23 \mathrm{~cm} /$ leaf $)$ was recorded in NIA-2004, followed by Larkana-2001 $(20.74 \pm 2.17 \mathrm{~cm})$. Moreover, the minimum leaf length $(7.28 \pm 0.19 \mathrm{~cm})$ was recorded in BL-4, followed by Gulabi-95 variety with leaf length of $11.00 \pm 0.88$ $\mathrm{cm}$. Accordingly, a highly significant difference $(\mathrm{P}<$ 0.001 ) was observed in the leaf lengths among various sugarcane varieties (Table 2).

\section{Sheath length}

Results regarding the sheath length of various sugarcane varieties evaluated in the study also elicited 
a significant difference $(\mathrm{P}<0.05)$ as the minimum and maximum length of sheath i.e., $8.23 \pm 0.18 \mathrm{~cm}$ and $2.66 \pm 0.14 \mathrm{~cm}$ was recorded for Larkana-2001 and Gulabi-95 varieties, respectively. The sheath length of Thatta-10, SPSG-26, BL-4, NIA-98, NIA-2004, L-116, AEC-82-1026 and AEC-86-223 varieties was recorded as $2.85 \pm 0.11 \mathrm{~cm}, 4.88 \pm 0.22 \mathrm{~cm}, 3.26 \pm 0.13$ $\mathrm{cm}, 4.74 \pm 0.25 \mathrm{~cm}, 5.48 \pm 0.51 \mathrm{~cm}, 7.80 \pm 6.56 \mathrm{~cm}$, and $6.20 \pm 0.33 \mathrm{~cm}$, respectively.

\section{Trichomes at top sheath}

Table 2 also indicated the number of trichomes counted at top sheath of different sugarcane varieties. According to results, maximum number of trichomes at top sheath were recorded in AEC-86-223 variety (59.75 \pm 4.09 trichomes per one-inch sheath), which was closely followed by Larkana-2001 (58.15 \pm 2.29 trichomes per one-inch sheath). The lowest trichomes counted at top sheath was recorded in Gulabi-95 (16.20 \pm 0.88 trichomes per one-inch sheath) and Thatta-10 (16.50 \pm 0.79 trichomes per one-inch sheath). Thus, the ANOVA results confirmed a highly significant difference $(\mathrm{P}<0.001)$ in the number of trichomes at top sheath among various sugarcane varieties studied.

\section{Mid sheath trichomes}

The results for trichomes counted at mid sheath showed significant $(\mathrm{P}<0.05)$ difference among various sugarcane varieties evaluated (Table 2). Accordingly, the maximum and minimum number of trichomes on mid sheath were recorded on Larkana-2001 $(158.80 \pm 5.67$ trichomes per one-inch sheath) and BL-4 (57.95 \pm 2.09 trichomes per one-inch sheath) varieties, respectively.

\section{Bottom sheath trichomes}

The number of trichomes recorded on various sugarcane varieties exhibited a highly significant $(\mathrm{P}<$ 0.001) difference among various sugarcane varieties. The maximum number of bottom sheath trichomes (78.30 \pm 3.17 trichomes per one-inch sheath) was observed on Larkana-2001 variety, followed by NIA$2004(68.25 \pm 3.25$ trichomes per one-inch sheath) and AEC-82-1026 (63.05 \pm 3.25 trichomes per one-inch sheath) varieties. Moreover, the minimum number of trichomes on bottom sheath $(16.95 \pm 0.77$ trichomes per one-inch sheath) was recorded on SPSG-26 variety, closely followed by L-116 (17.90 \pm 0.93 trichomes per one-inch sheath).
Stem borer infestation percentage

The analyzed data for cane infestation caused by $C$. infuscatellus is presented in Table 2 that indicated a significant $(\mathrm{P}<0.05)$ variation in varietal preference of stem borer on sugarcane as the highest infestation percentage $(15.15 \pm 1.21 \%)$ was recorded on Thatta10 variety, followed by AEC-82-1026 variety $(12.10 \pm 1.11 \%)$. Among sugarcane varieties, $C$. infuscatellus showed the least preference on L-116 variety with infestation percentage of $0.89 \pm 0.10 \%$, followed by NIA-2004 variety $(3.90 \pm 0.22 \%)$. The infestation percentage of $C$. infuscatellus on remaining sugarcane varieties i.e., Larkana-2001, SPSG-26, BL-4, NIA-98, AEC-86-223 and Gulabi-95 were $7.14 \pm 0.41 \%, 5.10 \pm 0.72 \%, 5.25 \pm 0.81 \%, 4.10 \pm 0.45 \%$, $9.10 \pm 0.95 \%$ and $6.15 \pm 0.66 \%$, respectively.

\section{Larval population}

Among sugarcane varieties, the maximum and minimum population of $C$. infuscatellus larvae was recorded on Thatta-10 $(1.94 \pm 0.27$ larvae per cane $)$ and L-116 (0.26 \pm 0.06 larvae per cane). Moreover, the population of $0.58 \pm 0.11$ larvae per cane, $1.06 \pm 0.21$ larvae per cane, $0.86 \pm 0.10$ larvae per cane, $0.38 \pm 0.08$ larvae per cane, $0.54 \pm 0.11$ larvae per cane, $1.66 \pm 0.15$ larvae per cane, $1.38 \pm 0.22$ larvae per cane and $1.18 \pm 0.17$ larvae per cane were recorded in Larkana-2001, SPSG-26, BL-4, NIA-98, NIA2004, AEC-821026, AEC-86-223 and Gulabi-95 varieties, respectively (Table 2 ). Accordingly, a highly significant difference $(\mathrm{P}<0.001)$ was recorded among different sugarcane varieties regarding the larval population of C. infuscatellus.

\section{Parasitism percentage}

The parasitism percentage of C. Alavipes on C. infuscatellus damaging different sugarcane varieties is shown in Table 2. The results indicated that percent parasitism of $C$. flavipes on $C$. infuscatellus on various sugarcane varieties differ significantly $(\mathrm{P}<0.05)$. Accordingly, the maximum parasitism of $C$. flavipes was observed on $C$. infuscatellus collected from Thatta-10 (14.82 $\pm 1.27 \%)$, followed by AEC-82-1026 (13.60 $\pm 0.86 \%)$. Moreover, the lowest $C$. flavipes parasitism was noticed on $C$. infuscatellus collected from L-116 (1.71 $\pm 0.02 \%)$, followed by NIA-98 (3.38 $\pm 0.09 \%)$, and NIA$2004(3.72 \pm 0.09 \%)$. The parasitism percentage of C. Alavipes observed on Larkana-2001, SPSG-26, BL-4, AEC-86-223 and Gulabi-95 varieties was $5.54 \pm 0.79 \%, 6.63 \pm 0.26 \%, 5.94 \pm 0.12 \%, 10.31 \pm 0.92 \%$ and $9.31 \pm 0.86 \%$, respectively. 


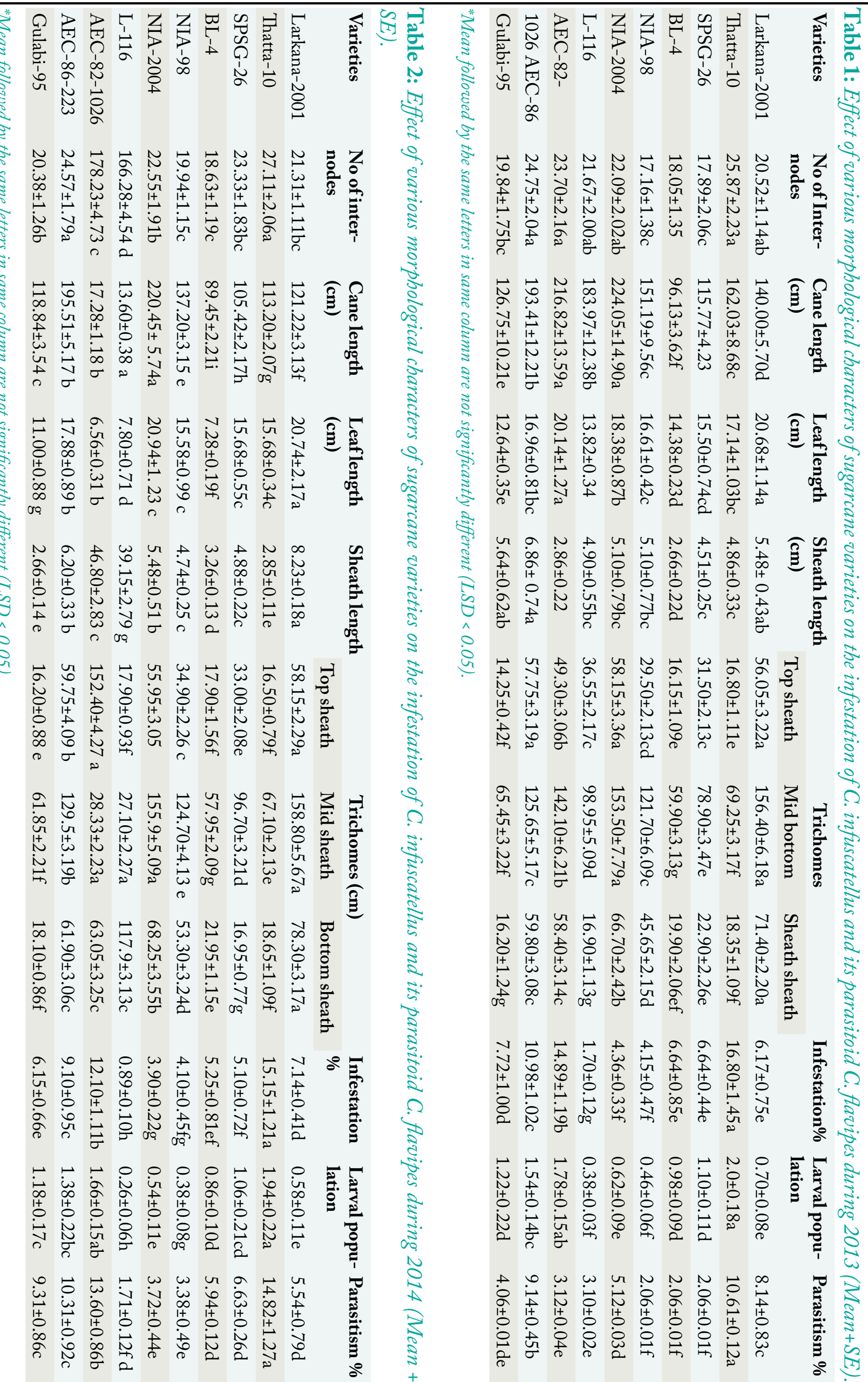


Correlation between various morphological characters of sugarcane varieties with population and infestation of $C$. infuscatellus and its parasitoid C. Alavipes during 2013

Results regarding correlation between various varietal characters of sugarcane varieties with population and infestation of $C$. infuscatellus and its parasitoid C. flavipes during 2013 are presented in Table 3. According to results, a significant and positive relationship was found between $C$. infuscatellus percentage infestation $(\mathrm{r}=0.8612, \mathrm{p}<0.0301)$, larval population $(\mathrm{r}=0.5790, \mathrm{p}<0.044)$ along with parasitism percentage of C. flavipes ( $\mathrm{r}=0.5050, \mathrm{p}$ $<0.047$ ) with the number of internodes on the various sugarcane varieties. Moreover, the infestation percentage of $C$. infuscatellus also showed significant, positive and intermediate correlation $(r=0.5925, \mathrm{p}$ $<0.0261$ ) with parasitism percentage of $C$. flavipes. In addition, the larval population of $C$. infuscatellus also exhibited a significant and positive association with C. infuscatellus infestation percentage $(\mathrm{r}=0.6929, \mathrm{p}$ $<0.0263$ ) and C. flavipes percentage parasitism ( $\mathrm{r}=$ 0.4282 , $p<0.0414$ ). No significant relationship was observed for the rest of the varietal characters of cane varieties with both pest and parasitoid population.

Correlation between various varietal characters of sugarcane varieties with population and infestation of $C$. infuscatellus and its parasitoid C. Alavipes during 2014

The correlation results for 2014 study were almost similar with that of 2013, as the number of internodes of sugarcane varieties elicited a significant, moderate and positive correlation $(\mathrm{r}=0.5974, \mathrm{p}<0.0482)$ only with percentage infestation of $C$. infuscatellus. Moreover, during 2014, rate of C. flavipes parasitism also showed a medium, positive and significant relation with infestation percentage of $C$. infuscatellus $(\mathrm{r}=0.4613, \mathrm{p}<0.0465)$, but a highly significant relationship with its larval population $(r=0.9849$, $\mathrm{p}<0.0001)$. A significant inter-relation was also observed between infestation percentage and larval population of $C$. infuscatellus $(\mathrm{r}=0.5221, \mathrm{p}<0.0374)$.

No other significant relationship was recorded in the study (Table 4).

Two years studies confirmed that there were significant variations among the sugarcane varieties for their morphological characteristics, which in turn affected the population and infestation of $C$. infuscatellus and parasitism percentage of $C$. flavipes on C. infuscatellus. Among sugarcane varieties studied, L-116 variety was found comparatively resistant with minimum infestation and larval population of $C$. infuscatellus, whereas, Thatta-10 variety was found to be the most susceptible showing maximum borer population and infestation. The infestation of other varieties was given in descending order towards the susceptibility as, AEC-821026 > AEC-86-223> Gulabi-95 > SPSG$26>$ BL-4 > Larkan-2001> NIA- 2004 > NIA-98 > 98. Thus, no complete resistant variety of sugarcane was found against the C. infuscatellus. Moreover, the presence of host i.e., $C$. infuscatellus on various cane varieties attracted the variable population of its parasitoid, C. flavipes as its maximum and minimum population was also recorded on Thatta-10 and L-116 variety. This variable population of both pests and parasitoid may be attributed to the highest number of internodes counted on Thatta-10 variety as they may support the feeding and movement of the pests, and accordingly, its parasitoid. Moreover, no significant effect of other varietal characters of sugarcane i.e., leaf length, sheath length, cane length and number of trichomes was recorded either on infestation of $C$. infuscatellus or parasitism percentage of $C$. flavipes. The findings of this study support the findings recorded by Sohu et al. (2008) who found that L-116 showed very good results against sugarcane borer with minimum losses. However, our results did not support the findings of Keerio et al. (2003) and Memon et al. (2003) who reported that the BL-4 sugarcane variety showed minimum infestation of $C$. infuscatellus.

Table 3: Correlation between various varietal characters of sugarcane varieties with population and infestation of $C$. infuscatellus and its parasitoid C. Alavipes during 2013.

\begin{tabular}{|c|c|c|c|c|c|c|c|c|c|}
\hline \multirow[t]{2}{*}{ Parameters } & \multirow{2}{*}{$\begin{array}{l}\text { No. of } \\
\text { internodes }\end{array}$} & \multirow{2}{*}{$\begin{array}{l}\text { Cane } \\
\text { length }\end{array}$} & \multirow{2}{*}{$\begin{array}{l}\text { Leaf } \\
\text { length }\end{array}$} & \multirow{2}{*}{$\begin{array}{l}\text { Sheath } \\
\text { length }\end{array}$} & \multicolumn{3}{|c|}{ Trichomes } & \multirow{2}{*}{$\begin{array}{l}\text { Infestation } \\
\text { percentage }\end{array}$} & \multirow{2}{*}{$\begin{array}{l}\text { Larval } \\
\text { population }\end{array}$} \\
\hline & & & & & & Middle & & & \\
\hline $\begin{array}{l}\text { on } \\
\text { ge }\end{array}$ & $\begin{array}{l}r=0.6812 \\
p=0.0301\end{array}$ & $\begin{array}{l}r=0.1887 \\
p=0.6016\end{array}$ & $\begin{array}{l}r=0.3451 \\
p=0.3288\end{array}$ & $\begin{array}{l}r=-0.1424 \\
p=0.6947\end{array}$ & & $\begin{array}{l}50 \\
8\end{array}$ & & - & $\begin{array}{l}929 \\
263\end{array}$ \\
\hline population & $\begin{array}{l}790 \\
44\end{array}$ & $\mathrm{p}=0$ & $\begin{array}{l}r=0.0807 \\
p=0.8247\end{array}$ & $\begin{array}{l}\mathrm{r}=0.0085 \\
\mathrm{p}=0.9814\end{array}$ & $\begin{array}{l}43 \\
9\end{array}$ & $\begin{array}{l}r=-c \\
p=0\end{array}$ & $\begin{array}{l}72 \\
8\end{array}$ & - & - \\
\hline $\begin{array}{l}\text { Parasitism } \\
\text { percentage }\end{array}$ & $\begin{array}{l}r=0.5055 \\
p=0.047\end{array}$ & $\begin{array}{l}r=0.3231 \\
p=0.3624\end{array}$ & $\begin{array}{l}r=-0.2161 \\
p=0.5487\end{array}$ & $\begin{array}{l}\mathrm{r}=0.0972 \\
\mathrm{p}=0.7893\end{array}$ & $\begin{array}{l}r=0.1702 \\
p=0.6384\end{array}$ & $\begin{array}{l}r=0.0769 \\
p=0.8328\end{array}$ & $\begin{array}{l}r=-0.1867 \\
p=0.6056\end{array}$ & $\begin{array}{l}r=0.5925 \\
p=0.0261\end{array}$ & $\begin{array}{l}r=0.4282 \\
p=0.0414\end{array}$ \\
\hline
\end{tabular}


Table 4: Correlation between various varietal characters of sugarcane varieties with population and infestation of $C$. infuscatellus and its parasitoid C. Aavipes during 2014.

$\begin{array}{lllllllll}\begin{array}{l}\text { No. of } \\ \text { internodes }\end{array} & \begin{array}{l}\text { Cane } \\ \text { length }\end{array} & \begin{array}{l}\text { Trichomes } \\ \text { Sheath }\end{array} & \begin{array}{l}\text { Infestation } \\ \text { sheath } \\ \text { length }\end{array} & \text { Top } & \text { Middle } & \begin{array}{l}\text { Leaf length } \\ \text { bottom }\end{array} & \begin{array}{c}\text { Percentage Popula- } \\ \text { tion }\end{array} \\ & & & & & & & \\ r=-0.5974 & \mathrm{r}=-0.6144 & \mathrm{r}=-0.3715 & \mathrm{r}=-0.4598 & \mathrm{r}=-0.4847 & \mathrm{r}=-0.5240 & \mathrm{r}=-0.1794 & - & \mathrm{r}=0.5221 \\ \mathrm{p}=0.0482 & \mathrm{p}=0.0587 & \mathrm{p}=0.2905 & \mathrm{p}=0.1812 & \mathrm{p}=0.1557 & \mathrm{p}=0.1200 & \mathrm{p}=0.6199 & \mathrm{p}=0.0374 \\ \mathrm{r}=0.2718 & \mathrm{r}=0.1190 & \mathrm{r}=-0.0347 & \mathrm{r}=-0.5055 & \mathrm{r}=-0.2676 & \mathrm{r}=-0.3183 & \mathrm{r}=-0.1574 & - & - \\ \mathrm{p}=0.4474 & \mathrm{p}=0.7434 & \mathrm{p}=0.9242 & \mathrm{p}=0.1361 & \mathrm{p}=0.4548 & \mathrm{p}=0.3701 & \mathrm{p}=0.6641 & \\ \mathrm{r}=0.3164 & \mathrm{r}=0.1721 & \mathrm{r}=0.0197 & \mathrm{r}=-0.4901 & \mathrm{r}=-0.2172 & \mathrm{r}=-0.2378 & \mathrm{r}=-0.0544 & \mathrm{r}=-0.4613 & \mathrm{r}=0.9849 \\ \mathrm{p}=0.3732 & \mathrm{p}=0.6346 & \mathrm{p}=0.9569 & \mathrm{p}=0.1504 & \mathrm{p}=0.5466 & \mathrm{p}=0.5082 & \mathrm{p}=0.8813 & \mathrm{p}=0.0465 & \mathrm{p}=0.0001\end{array}$

This variation in level of infestation on different varieties may be attributed to difference in geographical regions where the studies were undertaken. Moreover, significant influence of number of internodes was recorded on the population and losses of C. infuscatellus as Makhdum et al. (2001) also reported that C. infuscatellus infestation on cane stalks was higher compared to leaves and cane stubbles. Moreover, the same study also found significant role of number of tillers had with stem borer infestation. Khaliq and Warning, 2003) reported that stem borer infestation caused significant decrease in yield and juice quality for all evaluated varieties. However, sugarcane varieties with maximum trichomes on leaves were found partially resistant against stem borer infestation. Accordingly, no sugarcane variety was found completely resistant in this study although they showed great variation in the number of trichomes on their various parts. Therefore, it is evident from previous study of Abdullah et al. (2006) that morphological characteristics of different sugarcane varieties showed association with the stem borer infestation. As such, a significant but negative correlation between stem borer infestation and total shoot length has been reported by Kumar et al. (2018). Studies also reported that sheath length at bottom, mid and top cane portion also had association with the stem borer infestation and losses were decreased in canes with stronger bottom and mid portion sheath (Abdullah et al., 2005). Kishore et al. (2002) and Mailafiya et al. (2009) examined various sugarcane varieties against sugarcane stem borer infestation. They observed that varieties with higher number of trichomes showed minimum stem borer infestation, while the varieties having lower number of leaves and trichomes showed maximum infestation. Khan et al. (2013) reported that the infestation of $C$. infuscatellus was significantly highest on SPF-234, which possess maximum number of internodes, hence, their results supported the findings of this study. Another study by Muhammad et al. (2014) confirmed that $C$. partillus cause damage to both early and late maturing sugarcane varieties, where, its parasitoid's i.e., C. flavipes population was higher on the varieties which showed maximum infestation. Similarly, relatively higher population of $C$. flavipes was also recorded on the varieties which showed maximum infestation and larval population of C. infuscatellus.

\section{Conclusions and Recommendations}

A high variation was found in the morphological characters of different sugarcane varieties evaluated, that in response affected the population of both $C$. infuscatellus and its parasitoid, C. flavipes. Among varieties, highest population of $C$. infuscatellus was recorded on Thatta-10 variety, whereas L-116 suffered the lowest damage. Consequently, the highest parasitism of C. Alavipes on C. infuscatellus was also recorded on these varieties respectively. Moreover, among morphological characters, only the number of internodes showed a significant influence the infestation and larval population of $C$. infuscatellus along with parasitism of $C$. flavipes.

\section{Novelty Statement}

The morphological characters of sugarcane varieties especially number of internodes exhibited a significant impact of population of Chilo infuscatellus and accordingly to parasinization od Cotesia flavipes on it. Therefore, desirable sugarcane varieties should be exploited to lower the losses of C. infuscatellus and Enhance the parasitization of $C$. flavipes.

\section{Author's Contribution}

Bina Khanzada: Conducted the study and prepare 
the initial draft.

Arfan Ahmed Gilal: Overall management of the article including conceiving and designing the study, and finalization of manuscript.

Bhai Khan Solangi: Perform the analysis of data.

Imtiaz Ahmed Nizamani: Help in designing the study and finalization of manuscript.

\section{Conflict of interest}

The authors have declared no conflict of interest.

\section{References}

Abdullah, M., M.A. Alam, T. Ahmed and M.N.A. Siddiquee. 2006. Estimation of losses caused by stem borer, Chilo tumidicostalis Hampson, in sugarcane. Planter, 82(958): 33-38.

Abdullah, M., M.A. Alam, M.M. Biswas and M.A. Rahman. 2005. Efficacy of some cartap insecticides in controlling sugarcane stem borer. Indian Sugar, 55(6): 29-32.

Arian, M.Y., R.N. Panhwar, N.M. Gujar, M.A. Chohan,A.F. Rajput,A.F. Soomro and S.Junejo. 2011. Evaluation of new candidate sugarcane varieties for some qualitative and quantitative traits under Thatta agro-climatic conditions. J. Ann. Plant Sci., 21(2): 226-230.

Hussain, F., M.A. Sarwar and A.A. Chattha. 2007. Screening of some sugarcane genotypes for gur quality. J. Ann. Plant Sci.b 17(3-4): 76-78.

Keerio, H.K., R.N. Panhwar, Y.M. Memon, M.Y. Araien, M. Chohan and B.R. Qazi. 2003. Qualitative and quantitative performance of some promising and commercial sugarcane varieties under agro-climatic conditions of Thatta. Pak. J. Appl. Sci.b 3(10-12): 670-673. https://doi.org/10.3923/jas.2003.670.673

Khaliq, A. and P. Warning. 2003. Morpho-physical factors affecting resistance against top borer, Scirpophaga nivella F. in sugarcane. J. Agric. Res.b 41(1): 85-90.

Khan, M., R. Sultana, B.A. Bughio, A. Ali, B.K. Solangi and S. Kumar. 2013. Studies on the population dynamics of sugarcane stem borer, Chilo infuscatellus (Lepidoptera: Pyralidae) and its parasitoid Cotesia flavipes (Hymenoptera: Braconidae) in sugarcane in Hyderabad Region of Sindh. Sindh Univ. Res. J., (Sci. Ser.), 45(3): 542-545.

Kishore, P., S.R. Babu, U. Singh and G. Rai. 2002.
New sources of resistance against shoot fly, Atherigona soccata Rondani, stem borer, Chilo partellus (Swinhoe) and sugarcane leafhopper, Pyrilla perpusilla Walker in newly developed sorghum varieties and hybrids. J. Entomol. Res., 26(2): 101-112.

Kumar, K., M.S. Jaglan and T. Verma T. 2018. Population dynamics of early shoot borer, Chilo infuscatellus Snellen on sugarcane as influenced by weather conditions. J. Appl. Nat. Sci., 10(4): 1297-1302. https://doi.org/10.31018/jans. v10i4.1922

Mailafiya, D.M., B.P. Ru, E.W. Kairu, P.A. Calatayud and S. Dupas. 2009. Species diversity of lepidopteran stem borer parasitoids in cultivated and natural habitats in Kenya. J. Appl. Entomol., 133(6): 416-429. https://doi. org/10.1111/j.1439-0418.2009.01381.x

Makhdum, A.H., M.J.W. Cock and A. Shehzad. 2001. Effect of trash mulching on the infestation of stem borer Chilo infuscatellus Snellen, its natural enemies and on over all sugar productivity in the Habib Sugar Mills area at Nawabshah, Sindh. Pak. Sugar J., 16(3): 6-14.

Memon, Y.M., H.K. Keerio, R.N. Panhwar, B.R. Qazi, M.A Rajput and G.S. Unar. 2003. Yield response of different sugarcane varieties under agro-climatic conditions of Thatta. J. Appl. Sci., 4(1): 90-92. https://doi.org/10.3923/ jas.2004.90.92

Mohyuddin, A.L., G. Jilani, A.G. Khan, A. Hamza, A. Ahmed and Z. Mahmood. 1997. Integrated pest management of major cotton pests by conservation, redistribution, and augmentation of natural enemies. Pak. J. Zool., 29: 293-298

Mondal,P., S.Palit and B.Mondal.2012. Population dynamics and management of Lipaphis erysimi in mustard crop. In: Sustainable Agriculture and Environment (Rahim KB, Sarkar D, Roy, BC Eds.). New Delhi Publishers, New Delhi, India. pp. 291-298.

Muhammad, R., Q. Ahmed, N. Ahmed, M.M. Shah and N. Depar. 2014. Varietal responses on the population dynamics of sugarcane stem borer and its parasitoids. Acad. J. Agric. Res., 2(3): 87-92.

Muirhead, K.A., N.P. Murphy, M.N. Sallam, S.C. Donnellan and A.D. Austin. 2006. Mitochondrial DNA phylogeography of the Cotesia flavipes complex of parasitic wasps 
(Hymenoptera: Braconidae). Annales De La Société Entomologique De France, 42(3-4): 309-318. https://doi.org/10.1080/00379271.2 006.10697462

Ngi-Song, A.J. and W.A. Overholt. 1995. Host selection by Cotesia flavipes and Cotesia sessamiae (Hymenoptera: Braconidae) an example of tritrophic relationship in graminacious stemborer parasitoid system. In Integrating Biological Control and Host Plant Resistance. Proceeding of a CTA/ IAR/IIBC seminar. 9-14 October 1995, Addis Ababa. Ethiopia.pp. 172-181

Raza, M., A. Qadeer, A. Nazir, M.M. Shah and D. Nizamuddin. 2014. Varietal responses on the population dynamics of sugarcane stem borer and its parasitoids. Acad. J. Agric. Res., 2(3): 87-92.

Sajid, N. and M. Hamed. 2011. Biological control of sugarcane borers with inundative releases of Trichogramma chilonis (Ishii) (Hymenoptea: Trichogrammatidae) in farmers' fields. Pak. J. Agric. Sci., 48: 71-74.

Shahid, M.R., S. Anjum, J.A. Muhammad, D.G. Muhammad, M.A. Shahzad and S. Hussain. 2007. Effectiveness of Trichogramma chilonis (Ishii) (Hymen. Trichogrammatidae:) against Sugarcane stem borer Chilo infuscatellus (Lepidoptera: Pyralidae). Pak. Entomol., 29: 141-146.

Soerjani, M., 1998. Current trend in pesticide usage in some Asian countries. Environ. Impelic. Res. Pestic. International Atomic Energy Agency, Vienna Austria.pp. 219234

Sohu, I.A., A.M. Khaskheli, P.A. Baloch and B.A. Abro. 2008. Evaluation of yield and yield contributing parameters of different sugarcane (Saccharum officinarum L.) varieties under national uniform varietal yield trail. Pak. Sugar J., 23(1): 7-10. 